Approaches to Landscape 


\title{
Approaches to Landscape
}

\author{
Richard Muir
}

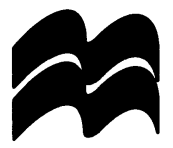


ISBN 978-0-333-69393-3 ISBN 978-1-349-27243-3 (eBook)

DOI 10.1007/978-1-349-27243-3

(C) Richard Muir 1999

Reprint of the original edition 1999

All rights reserved. No reproduction, copy or transmission of this publication may be made without written permission.

No paragraph of this publication may be reproduced, copied or transmitted save with written permission or in accordance with the provisions of the Copyright, Designs and Patents Act 1988, or under the terms of any licence permitting limited copying issued by the Copyright Licensing Agency, 90 Tottenham Court Road, London W1P 9HE.

Any person who does any unauthorised act in relation to this publication may be liable to criminal prosecution and civil claims for damages.

The author has asserted his right to be identified as the author of this work in accordance with the Copyright, Designs and Patents Act 1988.

First published 1999 by

MACMILLAN PRESS LTD

Houndmills, Basingstoke, Hampshire RG21 6XS

and London

Companies and representatives

throughout the world

ISBN 978-0-333-69392-6 hardcover

ISBN 978-0-333-69393-3 paperback

A catalogue record for this book is available from the British Library.

$\begin{array}{rrrrrrrrrr}10 & 9 & 8 & 7 & 6 & 5 & 4 & 3 & 2 & 1 \\ 08 & 07 & 06 & 05 & 04 & 03 & 02 & 01 & 00 & 99\end{array}$

Copy-edited and typeset by Povey-Edmondson Tavistock and Rochdale, England 


\section{Contents}

List of Illustrations

Introduction xiii

1. Landscape History and Landscape Heritage 1

2. The Practice of Landscape History 49

3. The Structure and Scenery Approach 99

4. Landscapes of the Mind 115

5. Landscape, Politics and Power 149

6. The Evaluation of Landscape 182

7. Symbolic Landscapes 212

8. The Aesthetic Approach to Landscape 244

9. Landscape and Place 271

$\begin{array}{ll}\text { Postscript } & 297\end{array}$

$\begin{array}{ll}\text { Index } & 304\end{array}$ 


\section{List of Illustrations}

1.1 To the British geographer, R.E. Dickinson, landscape was 'the scene within range of an observer's vision', like this scene from the English Lake District. (Richard Muir)

1.2 Physical settings do not determine the nature of

\& human culture. Here the same religious impulses find

1.3 similar expressions in megalithic circles on the low, water-girt plains of Orkney island at the Ring of Brodgar (1.2) and on an elevated platform commanding panoramic views of the Lakeland Fells at Castlerigg (1.3). (Richard Muir)

2.1 Strip lynchets pleating a hillside at Linton in Wharfedale. (Richard Muir)

2.2 Ancient or woodland countryside is exemplified in this air photograph of Luppitt in Devon, with dispersed settlement, small, irregular fields with thick hedgerows and winding lanes. (Cambridge University collection: British Crown Copyright/MOD, reproduced with permission of the Controller of Her Britannic Majesty's Stationery Office

2.3 Planned or champion countryside is represented by scenes like this aerial view of Orwell in Cambridgeshire, with enclosed communal ploughlands defined by geometrical boundaries and a general shortage of scenic detail and variety. (Cambridge University collection)

2.4 Air photography is a technique of immense value to the landscape historian. In this picture of the deserted medieval village of Hamilton, Lincolnshire, and its setting one can see the remains of the village in the 
centre of the picture, with its main street surviving as a holloway, its property boundaries and house sites and a rectangular homestead moat, while medieval ridge and furrow patterns give the surrounding fields a corduroy-like texture. (Cambridge University collection)

2.5 The landscape historian must read the clues contained in the landscape. Here the slight hollow winding between the trees was once the High Street of the village of Childerley in Cambridgeshire. (Richard Muir)

2.6 The skills of two landscape historians were employed to chart the earthworks of settlement, gardens and plough ridges at Croxton in Cambridgeshire, allowing a reconstruction of the history of the locality. (From A.E. Brown and C.C. Taylor, Cambridgeshire Earthwork Surveys VI, Proceedings of the Cambridge Antiquarian Society, vol LXXXII (1993).)

2.7 Boundaries of many kinds traverse the historic landscapes. Life depended upon land and territories had to be demarcated and defended. The territorial frontierwork of Devil's Dyke is still undated, but it may well belong to the late Roman or early Saxon periods. The effort involved in creating the banks and ditches of such linear earthworks underlines the importance attached to safeguarding land. (Richard Muir)

3.1 Geology can exert a powerful presence in the landscape. A landscape, settlement and economy built on slate in the region of Blaenau Ffestiniog in north Wales. (Richard Muir)

3.2 Rock type will usually influence the appearance of landscape. This is a glaciated landscape with the smooth slopes and rounded summits characteristic of the Skiddaw Slates in the Lake District. Neighbouring rocks of the Borrowdale Volcanics Series weather into much more craggy and rugged forms. (Richard Muir) 
3.3 This coastal landscape, on the north Somerset coast at 104 Kilve, owes its personality entirely to the Blue Lias beds which can be seen dipping towards the shore. (Richard Muir)

4.1 Meinig wrote that 'any landscape is composed not only of what lies before our eyes but what lies within our heads'. Some observers looking at this scene might regard the falling water as restful, while others could regard the rugged rocks and swirling currents as elements in a violent landscape. (Richard Muir)

4.2- Different landscapes evoke different psychological $120-1$

4.4 responses. Here the mist-shrouded view of the mountains around the Old Man of Storr on Syke (4.2) suggests mystery, the scene at Bayham Abbey (4.4) is mystical and the landscape seen from the summit of Carn Brea in Cornwall (4.3) acts like a bridge, combining elements of the mysterious and the mystical. (Richard Muir)

4.5 In the popular imagination, English villages seem to symbolise timelessness and stability, and this scene, at Lower Slaughter in the Cotswolds, would seem to encapsulate such sentiments. In fact, like so many others, the village has changed considerably over the centuries, with the built-up area expanding across a riverside green. (Richard Muir)

4.6 This rubble-walled and thatched cottage in 144

\& Northamptonshire (4.6) epitomises the romantic

4.7 vision of 'Village England'. Dwellings such as these, which were built in the vernacular styles of the English regions, inspired the construction of sentimental parodies, like this cottage orné in Bedfordshire (4.7). (Richard Muir)

5.1 Wiepking's contrasting of an 'undesigned cultural landscape' (a) with 'designed German cultural landscape' (b). (From Gert Groening 'The Feeling for Landscape - a German Example', Landscape Research 17 (3) $1992,108-15$ at p. 111) 
5.2 Built for the Duke of Marlborough following his victory over the armies of Louis XIV in 1704, Blenheim Palace is a spectacular expression of power in the landscape. The original gardens and park were formal, but the landscape was remodelled by Brown after 1764. (Cambridge University collection)

5.3 Wimpole Hall in Cambridgeshire, begun around 1640 and enlarged a century later when the property of the Earl of Hardwick, the Lord Chancellor. (Richard Muir)

5.4 The park surrounding Wimpole Hall was landscaped 160 by Lancelot Brown in the mid-eighteenth century and remodelled by Humphry Repton in 1801. In the foreground the ridge and furrow patterns from the former villagers' fields are plainly visible. (Richard Muir)

5.5 New Wimpole, the descendant of two villages 161 successively destroyed in the landscaping of Wimpole park. (Richard Muir)

5.6 Much of the English countryside derives from the exercise of might and influence. Amongst the most influential re-makers of the countryside were members of the Tudor landowning dysnasties, like the Knightleys of Fawsley Northamptonshire, who prospered by destroying villages and repopulating the land with sheep. (Richard Muir)

5.7 The disciplined geometry of Parliamentary Enclosure field walls in Nidderdale. (Richard Muir)

6.1 In the eighteenth century the landscaping taste of the educated classes was heavily influenced by the paintings of Claude, Poussin and Rosa. Elements from this painting, Coastal View of Delos and Aeneas, by Claude, were echoed in many new landscape parks of the time. (National Gallery, London) 
6.2 The orderly disposition of fields, hedgerows and hedgerow trees displayed in this air photograph from the Helperby locality of North Yorkshire would have appealed to the tastes of eighteenth century country landowners. (Cambridge University collection)

6.3 Wild and rugged countrysides, like this view of the Cuillins on Skye, were unattractive and threatening to the eighteenth-century mind. (Richard Muir)

6.4 From the time of Wordsworth and the Lake poets onwards, picturesque scenes, like this much photographed view of Ashness Bridge in Cumbria, have been widely regarded as the epitome of landscape beauty. (Richard Muir)

7.1 Landscapes contain symbols of many kinds; some can be translated, but some of the symbolism, like that associated with this Cumbrian stone circle, is mysterious. (Richard Muir)

7.2 It has been suggested that megalithic tombs, like this one at Poulnabrone in Co. Claire had strong symbolic associations. To outsiders they symbolised the fact that land had been held for generations by the community whose ancestors were contained in the tombs. They may also have symbolised the restoration of energy and resources to the earth when a leader was buried, perhaps compensating the land for the goodness robbed by cultivators. (Richard Muir)

7.3 It is said that landscape is a way of seeing. The

\& pictures of Ely cathedral (7.3) and the churchyard

7.4 (7.4) show how the way of seeing would be different were our eyes to be made sensitive to the infra-red radiation associated with living creatures and plants. (Richard Muir)

7.5 The powerful symbolic associations of landscape are often exploited in advertising and publicity. Here an idyllic passage of ancient countryside is invoked to 
represent Britain on the cover of a booklet concerning information technology and the British Library. (Andrew Jones/British Library)

8.1 Landscapes such as the one depicted in this view of

Crummock Water in Cumbria seem to pose problems for prospect-refuge theory. Though generally regarded as highly attractive, this scene is virtually devoid of trees or other cover and therefore has little to offer by way of refuges. (Richard Muir)

8.2 This landscape in upper Nidderdale meets the 252 demands of prospect-refuge theory. It provides a range of vantage points and also plenty of places where one can see without being seen. It is not parkland, but it has some distinct similarities. (Richard Muir)

8.3 The parkland at Holkham, in Norfolk, landscaped by 258 'Capability' Brown in 1762. (Cambridge University collection: British Crown Copyright (C) MOD, reproduced with permission of the Controller of Her Britannic Majesty's Stationery Office)

9.1- Completely different place associations are $286-7$

9.4 encountered with these contrasting human settings: the Northern industrial terrace (9.1); the picturesque old Southern village (9.2); the rugged upland setting (9.3); the flat, windswept Fenland countryside (9.4). (Richard Muir)

P.1 The replacement village at Milton Abbas, Dorset. (Richard Muir) 


\section{Introduction}

Interest in landscape has grown enormously in recent years. The pattern of this growth has not been of an amalgamating nature, as in a river system, but of a branching character, as in a tree. As different approaches to the understanding of landscape have been developed and refined the divisions between these different branches have widened, so that today there will be few landscape historians indeed who are conversant with the prevailing concepts of landscape iconography, and perhaps fewer post-modernist students of landscape who could interpret a pattern of earthworks at a deserted village site. As the study of landscape has grown, so its branches have grown apart.

The growth in enthusiasm for landscape studies has been sustained for more than two decades, but it is plain that, in the UK particularly, two strong and largely separate strands of interest have been involved. One is represented by a broadly-based upwelling of interest in landscape history among scholars and amateur enthusiasts, and the disciplinary backgrounds of some of the figures associated with the interpretation and popularisation of cultural landscapes underlines the interdisciplinary nature of this field of study: W. G. Hoskins (historian), Christopher Taylor (geographerturned-archaeologist), Oliver Rackham (botanist), Tom Williamson (archaeologist), Trevor Rowley (geographer/historian), M. W. Beresford (historian), Brian Roberts (geographer), Jack Ravensdale (historian), Mike Aston (geographer-turned-archaeologist) and Della Hooke (geographer). The other strand arises from the development of a new humanistic geography as a reaction to geography's drift into spatial science. Subsequently, this strand has given rise to interest in place, post-modernism, aesthetic approaches to landscape and symbolism in landscapes. Diversity is sometimes a source of strength in landscape studies, a protection against the tyranny of the current fad or an imposed standardisation of thinking. In some ways, however, it is a weakness: 


\section{xiv Introduction}

Despite the best efforts of the Landscape Research Group in the UK and the journal Landscape in the USA, there is no formalised discipline of landscape studies, with its own methodologies and university departments. In the absence of any organisational or disciplinary unity, landscape studies all too often consist of a great variety of unrelated perspectives, tied only loosely to the environment and its representation. (Mills, 1997 p. 122)

This book is not an attempt to present a new theory of landscape, and neither does it seek to advance one approach or interpretation at the expense of others. Rather, it aims to identify, introduce and explore the different approaches to landscape. As with the branches on a tree, some of these approaches are close and share connections, while others are further apart. The aesthetic approach and landscape evaluation are linked by the fact that both concern human tastes in landscape and they have part of their literatures in common. The political realities of life ensure that the studies of power and of symbolism in the landscape will frequently overlap, while the psychological aspects of the human relationship to landscape permeate most fields of enquiry. Within the broad area of landscape study different workers pursue their own specialisms, the nature of which will affect their interpretation of landscape in general and of other specialisms in particular. (My own specialist background is in the field of landscape history.)

The differences between some approaches are quite profound. Landscape historians concerned to discover the evolution of countrysides and towns have traditionally regarded landscape as being like a palimpsest (a document on which the original writing has been erased to make room for other writing but yet is still faintly visible). However, Daniels and Cosgrove, writing from a post-modern perspective, considered that: "landscape seems less like a palimpset whose "real" or "authentic" meanings can somehow be recovered with the correct techniques, theories or ideologies, than a flickering text displayed on the word-processor screen whose meaning can be created, extended, altered, elaborated and finally obliterated by the merest touch of a button' (1988 p. 8). Underlying this interpretation is a fundamental division in the comprehension of landscape. On the one hand there is the conventional practice of regarding landscape as a material or tangible portion of a natural and cultural environment. On the other there is the treatment of landscape as 'a way of seeing' which is associated with Daniels and Cosgrove and their 
disciples, who interpret landscape as a painterly way of seeing the world which creates a picturesque view (Duncan, 1995 p. 414).

There is also an implicit difference in outlook between those who might claim to examine cultural landscapes in a scientifically detached manner and those who rejoice in their own engagement with the landscape. Rose explained that:

Such pleasure in and awe of landscape is often celebrated by geographers, but with hesitation, even treated with suspicion. Pleasure in the landscape was often seen as a threat to the scientific gaze, and it was often argued that the geographer should not allow himself to be seduced by what were described as 'the sirens of terrae incognitae' (Wright, 1947, p. 1). (1992 p. 10)

Landscape has many facets and there are many ways in which it can be represented:

Landscape may be represented by painting, drawing or engraving; by photography, film and theatrical scenery; by writing, speech, and presumably even music and other 'sound images'. Before all these secondary representations, however, landscape is itself a physical and multisensory medium (earth, stone, vegetation, water, sky, sound and silence, light and darkness, etc.) in which cultural meanings and values are encoded, whether they are put there by the physical transformation of place in landscape gardening and architecture, or found in a place formed, as we say, 'by nature'. . . Landscape is a medium in the fullest sense of the word. It is a material 'means' (to borrow Aristotle's terminology) like language or paint, embedded in a tradition of cultural signification and communication, a body of symbolic forms capable of being invoked and reshaped to express meaning and values. (Mitchell, 1994 p. 14)

The different interpretations applied to 'landscape' have been explored by Barrell, who considers that the term arose as a painter's word:

it was introduced from the Dutch in the sixteenth century to describe a pictorial representation of countryside, either as the subject itself of a picture, or as the by-work in a portrait, the background of scenery behind the main subject. Later the word 


\section{xvi Introduction}

came to include within its meaning both this sense, of countryside represented in a picture, and another, more loose, of a piece of countryside considered as a visual phenomenon. (1972 p. 1)

He added that:

Both these senses of the word 'landscape' had this in common, that they referred to a tract of land, or its representation in painting, which lay in prospect - that is to say, which could be seen all at one glance, from a fixed point of view; and in this respect both senses referred to particular locations.

Later, in the mid-eighteenth century, however, a more general meaning became associated with the word so that one could speak of 'the landscape' of a place, and this sense goes beyond the spatial confinement which the sense of $a$ landscape as a prospect had imposed, and landscape acquired a meaning similar to 'terrain'.

Perhaps the most lucid explanation of the ambiguities surrounding the multiple layers of meaning associated with landscape was provided by Cosgrove (1984). He wrote of the active engagement of the human subject with the material object and the suggestion that 'area' and 'region' might be regarded as the equivalents of 'landscape': 'In other words landscape denotes the external world mediated through subjective human experience in a way that neither region nor area immediately suggest. Landscape is not merely the world we see, it is a construction, a composition of that world. Landscape is a way of seeing the world' (p. 13). The alternative identification of landscape as a passage of scenery which is seen rather than perceived was described by Bryan (1958 p. 1): 'Landscape, the dictionary tells us, is a portion of land or territory which the eye can comprehend at a single view including all the objects it contains.'

The location of landscape study in relation to other academic disciplines has changed with the passing years. Before the Second World War, the study of landscape was widely regarded as being at the very core of geography, and even in 1958, P.W. Bryan, the President of the Geographical Association, felt able to claim that:

the essential core of geography is the relationship between human activity and the physical setting or stage upon which human activity takes place ... this relationship itself is expressed in the 
landscape which results from the changes and adaptations of the physical background made by man in his efforts to satisfy his needs ... with the study and interpretation of this changed landscape as its central feature geography has a distinctiveness of outlook as a whole which marks if off from other subjects. (1958 p. 1)

In the 1950s and 1960s, however, landscape fell from favour in geography. In his The Nature of Geography of 1939, Richard Hartshorne, geography's leading guru, had rejected landscape as the central organising concept of geography and argued that the concept of landscape adopted in American cultural geography derived from the German Landschaft which had two meanings, one being 'a restricted piece of land' while:

It was, however, also used, as in English, to refer to the 'appearance of a land as we perceive it', e.g. 'the section of the earth surface and sky that lies in our field of vision as seen in perspective from a particular point'. This 'aesthetic' usage of the term enabled users to shift 'from the landscape as sensation to the objects that produce that sensation'. (Olwig, 1996 p. 630)

This, according to Hartshorne, caused confusion, with the same word being used in two different ways: 'Hartshorne's solution to the problem of landscape was essentially to abandon it in favour of geography as a science of region and space' (Olwig, 1996).

The subjective qualities which made landscape unacceptable to geographers in an era of spatial science and quantification would later commend it to geographers who were disorientated and disillusioned by the excesses and failures of the positivist movement. In 1985 Cosgrove wrote that:

Recently, and primarily in North America, geographers have sought to reformulate landscape as a concept whose subjective and artistic resonances are to be actively embraced. They allow for the incorporation of individual, imaginative and creative human experience into studies of the geographical environment, aspects which geographical science is claimed to have devalued at best and at worst ignored. (p. 45)

He continued: 'American humanist geographers have adopted landscape for the very reasons that their predecessors rejected it. 
It appears to point towards the experiential, creative and human aspects of our environmental relations, rather than to the objectified, manipulated and mechanical aspects of those relations'. Landscape, though, did not provide a banner under which all factions could unite, and in 1994 Duncan commented: 'There is little question that the new cultural geography is itself fragmenting. For example on the one hand there is a group of scholars who primarily analyse landscapes and, on the other, there are those who concentrate on space and place' (p. 362).

Cosgrove noted that: 'The frequent association in geographical writing of landscape with studies of the impact of human agency in altering the physical environment serves to remind us that landscape is a social product' (1984 p. 14). Several writers commented on the importance of landscape in studies of the relationship between humans and their setting, but there was lively discussion concerning the direction which such studies should follow:

The study of landscape provides for geographers a means of analysing and organizing the surrounding material environment, confirming the major tenet that we look to that material environment for concrete expression of the facts of human experience. Yet despite the well-established position of landscape study within the discipline there remain questions concerning how landscape is defined, and even greater questions concerning the relationship between landscapes and human beings. (Kobayashi, 1989 p. 165)

Kobayashi also writes: 'Geographical definitions of landscape abound, of course, but they are seldom critical, and an attempt to follow through upon upon the logic of these many definitions leads to many loose ends and contradictions.'

Here, I focus on the different approaches to landscape study. A certain amount of subjective judgement has been involved in the identification of these approaches. Were the task to be attempted by a selection of landscape enthusiasts then some approaches would have been recognised by all, while in other respects the choices might be different. Landscape history, landscape evaluation, the perception of landscape, an aesthetic approach, one concerning symbolism or iconography and one concerning the relationship of structure and scenery would probably feature on virtually every list. There is no sign of any halt to the growth in interest in landscape, but whether in years to come there will be a progress to a more coherent discipline 
of landscape studies or whether, instead, the divisions between the objective and subjective appreciations of landscape will deepen remains to be seen.

\section{Note}

I am grateful to my colleague, Dr Heather Norris Nicholson, for her comments on a part of the draft.

\section{References}

Barrell, J. The Idea of Landscape and the Sense of Place 1730-1840 (Cambridge: Cambridge University Press, 1972).

Bryan, P. W. 'Geography and landscape' Geography 43 (1958) pp. 1-9.

Cosgrove, D. Social Formation and Symbolic Landscape (London: Croom Helm, 1984).

Cosgrove, D. 'Prospect, perspective and the evolution of the landscape idea' Transactions of the Institute of British Geographers NS 10 (1985) pp. 4562.

Daniels, S. and Cosgrove, D. 'Introduction: iconography and landscape' in Cosgrove, D. and Daniels, S. (eds), The Iconography of Landscape (Cambridge: Cambridge University Press, 1988).

Duncan, J.S. 'The politics of landscape and nature, 1992-3' Progress in Human Geography 18 (1994) pp. 361-70.

Duncan, J. S. 'Landscape geography 1992-3' Progress in Human Geography 19 (1995) pp. 41-22.

Hartshorne, R. The Nature of Geography (Lancaster, Pennsylvania: Association of American Geographers, 1939).

Kobayashi, A. 'A critique of dialectical landscape' in Kobayashi, A. and Mackenzie, S. (eds), Remaking Human Geography (Boston: Unwin Hyman, 1989) pp. 164-83.

Mills, S. F. The American Landscape (Edinburgh: Keele University Press, 1997).

Mitchell, W. J. T. 'Imperial landscape' in W. J. T. Mitchell (ed.), Landscape and Power (Chicago: University of Chicago Press, 1994) pp. 5-34.

Olwig, K. R. 'Recovering the substantive nature of landscape' Annals of the Association of American Geographers 86 (1996) pp. 630-53.

Rose, G. 'Geography as a science of observation: the landscape, the gaze and masculinity' in Driver, F. and Rose, G. (eds), Nature and Science: Essays in the History of Geographical Knowledge, Institute of British Geographers Historical Geography Research Series No. 28 (1992) pp. 8-18.

Wright, J.K. 'Terrae incognitae: the place of the imagination in geography' Annals of the Association of American Geographers 37 (1947) pp. 1-15. 